\title{
Determination of Essential \& Toxic Metals and Its Transversal Pattern from Soil to Tea Brew
}

\author{
Piar Chand, Ruchi Sharma, Ramdeen Prasad, Rakesh Kumar Sud, Yogesh B. Pakade
}

Institute of Himalayan Bioresource Technology, Council of Scientific and Industrial Research, Palampur, India. Email: yogesh_pakade@yahoo.com

Received June 14 ${ }^{\text {th }}, 2011$; revised September $13^{\text {th }}, 2011$; accepted September $21^{\text {st }}, 2011$.

\begin{abstract}
The soil $p H$ of tea garden was acidic (4.6 - 5.3) with organic contents ranging between $0.91 \%-1.09 \%$. Available potassium concentration was predominantly found in the range of $167-208 \mathrm{mg} / \mathrm{kg}$ followed by the nitrogen (150 - 189 $\mathrm{mg} / \mathrm{ha}$ ) and phosphorus (42 - $169 \mathrm{mg} / \mathrm{kg}$ ). The Fe content was the one of the predominant heavy metal in soil (5494 $5627 \mathrm{mg} / \mathrm{kg})$ followed by $\mathrm{Mn}(245-435 \mathrm{mg} / \mathrm{kg}), \mathrm{Zn}(30-111 \mathrm{mg} / \mathrm{kg})$ and $\mathrm{Cu}(22-51 \mathrm{mg} / \mathrm{kg})$. The concentration of toxic heavy metals $\mathrm{Pb}, \mathrm{Ni}$, and $\mathrm{Cd}$ in tea leaves, made tea and its infusions were too low. The level of most abundant essential heavy metals in tea infusion was Zn ranging from $0.09-0.52 \mathrm{mg} / \mathrm{kg}$ followed by $\mathrm{Mn} 0.10-0.42 \mathrm{mg} / \mathrm{kg}$. The level of Fe and $\mathrm{Cu}$ was ranging from $0.068-0.073 \mathrm{mg} / \mathrm{kg}$ and $0.007-0.04 \mathrm{mg} / \mathrm{kg}$ in tea infusion respectively. The levels of all essential and the toxic metals were compared well with the other parts of the world.
\end{abstract}

Keywords: Tea, Heavy Metals, Physico-Chemical, Soil, Atomic Absorption Spectrophotometer (AAS)

\section{Introduction}

Tea (Camellia sinensis L.) is a perennial shrub, which is grown commercially in about 30 countries. The major tea exporting countries of the world are Kenya, China, India, Indonesia and Sri Lanka [1]. It is one of the most popular beverages in the world [2-6] and is a rich source of some essential dietary metals $[1,7]$ and metal-binding polyphenols [8]. Tea contains several minerals, trace elements, antioxidant and therefore considered good healthy beverages [9]. The environmental temperature of $18^{\circ} \mathrm{C}$ $30^{\circ} \mathrm{C}$ and soil temperature between $20^{\circ} \mathrm{C}-25^{\circ} \mathrm{C}$ are optimal for the plant growth. High annual rain fall and air humidity are other important weather requirement for cultivation of tea crops [5]. Tea is grown in a verity of soil type such as alluvial soils, drained peat, sedimenttary from gneiss and granite, and soils derived from volcanic ash [5]. Its growth is favoured in acidic conditions, with $\mathrm{pH}$ values ranging from 4.5 to 6.0 [10]. Although it will grow in soil $\mathrm{pH}$ as low as 4.0 , soil $\mathrm{pH}$ higher than 5.6 is considered unsuitable without $\mathrm{pH}$ adjustment of the soil. Soil with $\mathrm{pH}$ higher than 6.5 are not amenable to treatment for commercial tea growing [11].

A various reports have discussed the potential health implication of metal in tea, particularly tea bushes is known to accumulate trace metals [12]. Very recent re- search finding indicated the positive and negative effect of drinking tea on the health [13]. It was pointed out that some of the beneficial effects of drinking tea are prevention of chronic and cardiovascular disease, cancer, antioxidative detoxification and removal of cadmium in administered rats [14]. Tea contents both essential and toxic elements such as $\mathrm{Ca}, \mathrm{Na}, \mathrm{K}, \mathrm{Mg}$ and $\mathrm{Mn}$ are present at $\mathrm{mg} / \mathrm{g}$ level, whereas elements such as $\mathrm{Cr}, \mathrm{Fe}, \mathrm{Co}, \mathrm{Ni}, \mathrm{Cu}$, $\mathrm{Zn}$ and $\mathrm{Cd}$ are present at level of few $\mu \mathrm{g} / \mathrm{L}[15]$.

It is known that the source of heavy metal contamination in tea could be cause by uptake of metal from soil. The soil is contaminated by different type and amount of chemical substances added for improving the tea production. As a result, soil pollution by heavy metals becoming conspicuous. Therefore, control of tea quality and soil management has become very imperative. Tea plants (Camellia sinensis) can take up metals from the soil, and inevitably, proportion will be transported to the tea leaves, which are prepared one of the most popular beverages in the world. Therefore the level of heavy metal concentration in tea leaves play a major role to assess the quality of tea due to stringent regulatory limit set by the government agencies. Thus this study is, proposed to assess the uptake level of essential and toxic metals from soil to tea leaves and infusion of the tea garden plot that are grown in Institute farm. 


\section{Material and Methods}

\subsection{Study Site, Sample Collection and Its Preparation}

One measuring plot of tea garden of institute experimenttal farm was selected for this investigation. The general information of plot of tea garden including area, age, was summarized in Figure 1. Nine sampling spots were chosen for collection of soil, fresh tea leaves in descending order. Soil samples at depth of $20 \mathrm{~cm}$ and corresponding tea bush leaves samples were collected. Tea leaves samples were dried at room temperature, and rolled to prepared made tea in institute tea factory. Soil samples were dry at room temperature and then passed through a $2 \mathrm{~mm}$ nylon sieve. For organic matter determination the soil sample was ground more finely and passed through 0.5 $\mathrm{mm}$ sieve. The collected soil samples were subjected to measurement of fundamental chemical properties (viz. $\mathrm{pH}, \%$ carbon, $\%$ nitrogen, $\%$ phosphoprus and $\%$ potassium) and heavy metal concentrations using Atomic Absorption Spectrophotometer.

\subsection{Physico-Chemical Parameter of Soil}

Chemical properties of soils were mainly analyzed according to the soil standard methods of analysis (Committee of Soil Standard Methods for Analyses and Measurements (ed), 1986). The $\mathrm{pH}$ was measured (Cyberscan PC510, Eutech, Singapore) in the suspension having a soil: water ratio of 1:2. The organic carbon content was determined by the Tyurin method and multiplied by the coefficient of 1.724 to give the organic matter content [16]. The total nitrogen content was determined by the Kjeldahl method. The total phosphorus content was determined by the ascorbic acid method after decomposition with perchloric acid. The total potassium was determined by Flame Photometer (1381E, EI make, Chandigarh).

\subsection{Heavy Metal Analysis}

Analysis of heavy metal in tea leaves, made tea infusion and soil samples were carried out in triplicate as follows: The digestion was carried out with $1 \mathrm{~g}$ of sample in glass digestion tube of $250 \mathrm{~mL}$ along with $15 \mathrm{~mL}$ of nitric acid $\left(\mathrm{HNO}_{3}\right)$ at $140^{\circ} \mathrm{C}$. The content was evaporated to dryness. The dried sample treated by $3 \mathrm{ml}$ of perchloric acid $\left(\mathrm{HClO}_{4}\right)$ for further oxidation from the sample solution for $30 \mathrm{~min}$ at $245^{\circ} \mathrm{C}$. After digestion cool the content, filter and made up to $100 \mathrm{~mL}$ with distilled water. The heavy metal measurement were performed with a Shimadzu model AA 6300 Atomic Absorption Spectrophotometer (Tokyo Japan). The Hallow cathode lamps (HAMA- MATSU PHOTONICS K.K. JAPAN) of metal used as radiation source.

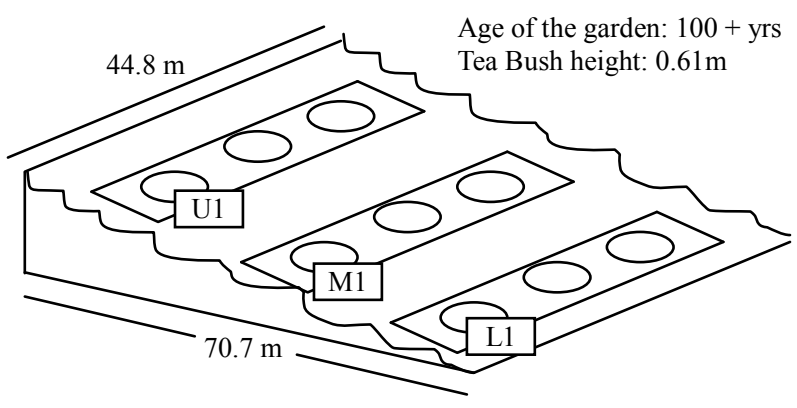

Figure 1. Schematic diagram of tea garden plot and its sampling sites (U1: Upper location; M1: Middle location; L1: Lower location).

\section{Results}

\subsection{Recovery Test}

Recovery tests using the above proposed methods were performed for both the soil and tea leaves sample by non-spiked and spiked samples. As shown in Table 1, the results of percentage recoveries for all the studied metals in soil were between $80 \%$ to $112 \%$. The values of percentage recoveries for the studied micronutrient and toxic metals in the tea leaves samples were $\geq 80$ except $\mathrm{Mn}$ and $\mathrm{Cu}$ (Table 2). The result of recoveries of all the metals in both soil and tea leaves are within the acceptable range [17].

\subsection{Physico-Chemical Properties and Metal Concentration of Soil}

Chemical properties of soil in the tea garden as shown in Table 3. The organic matter content was found in the range of $0.90 \%$ to $1.09 \%$. The total $\mathrm{N}$ content ranged from 150 to $189 \mathrm{~kg} / \mathrm{ha}$. The total phosphorus and potassium content ranged from 42 to $169 \mathrm{mg} / \mathrm{kg}$ and 167 to $208 \mathrm{mg} / \mathrm{kg}$ in the tea garden soils. The total metals concentrations in tea garden soil are given in Table 4. Thus $\mathrm{Fe}$ is the predominant metal within the concentration range of 5494 to $5627 \mathrm{mg} / \mathrm{kg}$ in these soils whereas $\mathrm{Mn}$ content in the range of $245-435 \mathrm{mg} / \mathrm{kg}$. The total concentration of micronutrient such as $\mathrm{Zn}(30-111 \mathrm{mg} / \mathrm{kg})$ and $\mathrm{Cu}(22-51 \mathrm{mg} / \mathrm{kg})$ in the tea garden soil. On the other hand, the level of toxic heavy metal $\mathrm{Cd}$, Ni ranges from 6.57 to $6.99 \mathrm{mg} / \mathrm{kg}$ and 3.1 to $4.0 \mathrm{mg} / \mathrm{kg}$. The level of $\mathrm{Pb}$, the other tested toxic metal, in all soil sample was found to be below detection limit by the present analytical techniques.

\subsection{Transversal Pattern of Essential and Toxic Metals}

Table 5 showed the uptake of selected metals from tea leaves to infusion in this study. The heavy metal included cadmium $(\mathrm{Cd})$, Nickel $(\mathrm{Ni})$ and Lead $(\mathrm{Pb})$ was called a 
toxic metal. The four essential trace elements included Iron $(\mathrm{Fe})$, Copper $(\mathrm{Cu})$ Manganese $(\mathrm{Mn})$ and $\mathrm{Zinc}(\mathrm{Zn})$. The cadmium content in the collected green tea leaves was found below the permissible limit of $1.5 \mathrm{mg} / \mathrm{kg}$. The dissipation of cadmium from soil to fresh tea leaves was found in the range of $3.02 \%-4.2 \%$ while, cadmium concentration was not detected in processed made tea and its infusion. The Ni concentration in green shoots was found

Table 1. Method recoveries of metal in soil.

\begin{tabular}{cccccccc}
\hline Element & Base value $(\mathrm{mg} / \mathrm{Kg})$ & Quantity found $(\mathrm{mg} / \mathrm{Kg})$ & Quantity added $(\mathrm{mg} / \mathrm{Kg})$ & Recovery $(\%)^{\mathrm{b}}$ & Linear equation & $\mathrm{r}^{2}$ & \\
\hline $\mathrm{Cd}$ & 9.57 & 2 & 11.76 & 109 & $\mathrm{y}=0.021 \mathrm{x}$ & 0.9998 \\
$\mathrm{~Pb}$ & - & 2 & 1.65 & 82.5 & $\mathrm{y}=0.522 \mathrm{x}$ & 0.9996 \\
$\mathrm{Zn}$ & 40.45 & 2 & 42.69 & 112 & $\mathrm{y}=0.902 \mathrm{x}$ & 0.9700 \\
$\mathrm{Mn}$ & 266.51 & 2 & 268.11 & 80 & $\mathrm{y}=0.200 \mathrm{x}$ & 0.9993 \\
$\mathrm{Cu}$ & 16.56 & 2 & 18.38 & 91 & $\mathrm{y}=0.129 \mathrm{x}$ & 0.9995 \\
$\mathrm{Ni}$ & 27.57 & 2 & 29.80 & 111 & $\mathrm{y}=0.090 \mathrm{x}$ & 0.9987 \\
$\mathrm{Fe}$ & 1504.44 & 2 & 1506.62 & 109 & $\mathrm{y}=0.093 \mathrm{x}$ & 0.9998 \\
\hline
\end{tabular}

Recovery test ${ }^{\mathrm{b}}=100^{*}$ (found-base/added).

Table 2. Method recoveries of metal in tea leaves.

\begin{tabular}{cccccccc}
\hline Element & Base value $(\mathrm{mg} / \mathrm{Kg})$ & Quantity added $(\mathrm{mg} / \mathrm{Kg})$ & Quantity found $(\mathrm{mg} / \mathrm{Kg})$ & Recovery $(\%)^{\mathrm{b}}$ & Linear equation & $\mathrm{r}^{2}$ & \\
\hline $\mathrm{Cd}$ & - & 3 & 3.1 & 100 & $\mathrm{y}=0.820 \mathrm{x}$ & 0.9993 \\
$\mathrm{~Pb}$ & 0.85 & 3 & 3.9 & 80.2 & $\mathrm{y}=0.023 \mathrm{x}$ & 0.9999 \\
$\mathrm{Zn}$ & 41.78 & 3 & 44.71 & 97 & $\mathrm{y}=0.578 \mathrm{x}$ & 0.990 \\
$\mathrm{Mn}$ & 380.91 & 1 & 381.47 & 56 & $\mathrm{y}=1.507 \mathrm{x}$ & 0.9795 \\
$\mathrm{Cu}$ & 25.71 & 1 & 26.12 & 41 & $\mathrm{y}=0.121 \mathrm{x}$ & 0.9985 \\
$\mathrm{Ni}$ & 20.39 & 1 & 21.44 & 105 & $\mathrm{y}=0.110 \mathrm{x}$ & 0.9997 \\
$\mathrm{Fe}$ & 221.04 & 1 & 221.84 & 80 & $\mathrm{y}=0.102 \mathrm{x}$ & 0.9902 \\
\hline
\end{tabular}

Recovery test ${ }^{b}=100^{*}$ (found-base/added).

Table 3. Physico-chemical characterization of tea.

\begin{tabular}{ccccccc}
\hline Sample & Location & $\mathrm{pH}$ & Carbon \% & Potassium (mg/Kg) & Nitrogen (Kg/ha) & Phosphorus (mg/Kg) \\
\hline \multirow{3}{*}{ Soil } & $\mathrm{U1}^{\mathrm{a}}$ & $5.18 \pm 0.92$ & $1.09 \pm 0.15$ & $171 \pm 58$ & $189 \pm 6$ & $169 \pm 68$ \\
& $\mathrm{M1}^{\mathrm{a}}$ & $4.65 \pm 0.16$ & $1.01 \pm 0.21$ & $167 \pm 32$ & $187 \pm 6.3$ & $88 \pm 48$ \\
& $\mathrm{L1}^{\mathrm{a}}$ & $5.32 \pm 0.94$ & $0.90 \pm 0.29$ & $208 \pm 82$ & $150 \pm 19$ & $42 \pm 21$ \\
\hline
\end{tabular}

${ }^{\mathrm{a}}$ Values $($ Mean $\pm \mathrm{SD})(\mathrm{n}=3)$

Table 4. Heavy metals concentration in soil.

\begin{tabular}{|c|c|c|c|c|c|c|c|}
\hline \multirow{2}{*}{ Location } & \multicolumn{7}{|c|}{ Heavy metals (mg/Kg) } \\
\hline & $\mathbf{P b}$ & Cd & $\mathrm{Ni}$ & Zn & Mn & $\mathbf{F e}$ & $\mathbf{C u}$ \\
\hline $\mathrm{U} 1^{\mathrm{a}}$ & ND & $6.989 \pm 1.45$ & $4.04 \pm 0.72$ & $111.5 \pm 9.75$ & $435.44 \pm 140$ & $5556.33 \pm 677.92$ & $29.38 \pm 6.58$ \\
\hline $\mathrm{M}^{\mathrm{a}}$ & ND & $6.567 \pm 1.27$ & $3.8 \pm 0.067$ & $40.0 \pm 3.5$ & $352.77 \pm 21.00$ & $5627.44 \pm 139.77$ & $22.32 \pm 9.97$ \\
\hline $\mathrm{L}^{\mathrm{a}}$ & ND & $6.926 \pm 3.67$ & $3.10 \pm 0.21$ & $30.0 \pm 3.44$ & $245.35 \pm 35.00$ & $5494.11 \pm 189.54$ & $51.14 \pm 12.26$ \\
\hline
\end{tabular}

${ }^{\mathrm{a}}$ Values $($ Mean $\pm \mathrm{SD})(\mathrm{n}=3)$. 
Table 5. Heavy metals concentration in fresh leaves, made tea and tea brew.

\begin{tabular}{|c|c|c|c|c|c|c|c|c|}
\hline \multirow{2}{*}{ Samples } & \multirow{2}{*}{ Location } & \multicolumn{7}{|c|}{ Heavy metals $(\mathrm{mg} / \mathrm{Kg})$} \\
\hline & & $\mathrm{Pb}$ & $\mathrm{Cd}$ & $\mathrm{Ni}$ & $\mathrm{Zn}$ & $\mathrm{Mn}$ & $\mathrm{Fe}$ & $\mathrm{Cu}$ \\
\hline \multirow{3}{*}{ Fresh tea leaves } & $\mathrm{U} 1^{\mathrm{a}}$ & ND & $0.230 \pm 0.0$ & $0.37 \pm 0.18$ & $7.13 \pm 1.80$ & $64.48 \pm 39.58$ & $9.54 \pm 5.3$ & $2.17 \pm 0.31$ \\
\hline & $\mathrm{M}^{\mathrm{a}}$ & ND & $0.199 \pm 0.01$ & $0.98 \pm 0.20$ & $6.75 \pm 2.25$ & $83.99 \pm 33.67$ & $9.013 \pm 2.2$ & $3.44 \pm 0.21$ \\
\hline & $\mathrm{L}^{\mathrm{a}}$ & ND & $0.29 \pm 0.06$ & $1.36 \pm 0.20$ & $4.27 \pm 1.59$ & $103.35 \pm 30.6$ & $9.707 \pm 3.7$ & $3.69 \pm 0.41$ \\
\hline \multirow{3}{*}{ Made tea } & $\mathrm{U} 1^{\mathrm{a}}$ & ND & ND & ND & $0.10 \pm 0.02$ & $1.49 \pm 0.83$ & $0.275 \pm 0.05$ & $0.092 \pm 0.02$ \\
\hline & $\mathrm{M}^{\mathrm{a}}$ & ND & ND & ND & $0.095 \pm 0.018$ & $2.05 \pm 0.85$ & $0.341 \pm 0.06$ & $0.32 \pm 0.078$ \\
\hline & $\mathrm{L}^{\mathrm{a}}$ & ND & ND & ND & $0.080 \pm 0.024$ & $1.81 \pm 0.09$ & $0.403 \pm 0.07$ & $0.579 \pm 0.27$ \\
\hline \multirow{3}{*}{ Tea brew } & $\mathrm{U} 1^{\mathrm{a}}$ & ND & ND & ND & $0.321 \pm 0.187$ & $0.424 \pm 0.42$ & $0.085 \pm 0.01$ & $0.040 \pm 0.002$ \\
\hline & $\mathrm{M}^{\mathrm{a}}$ & ND & ND & ND & $0.098 \pm 0.020$ & $0.106 \pm 0.04$ & $0.073 \pm 0.008$ & $0.007 \pm 0.004$ \\
\hline & $\mathrm{L}^{\mathrm{a}}$ & ND & ND & ND & $0.523 \pm 0.05$ & $0.318 \pm 0.03$ & $0.068 \pm 0.02$ & $0.008 \pm 0.004$ \\
\hline
\end{tabular}

${ }^{\mathrm{a}}$ Values $($ Mean $\pm \mathrm{SD})(\mathrm{n}=3)$; ND: not detected.

in the ranged of $0.37-1.36 \mathrm{mg} / \mathrm{kg}$, while processed made tea, and its infusion free from $\mathrm{Ni}$ contamination. The manganese content in the green shoots of tea garden was in the ranged of $64-103 \mathrm{mg} / \mathrm{kg}$ and that of proceeded made tea content was to be between $1.49-2.05 \mathrm{mg} / \mathrm{kg}$ From Table 5 it revealed that the dissipation of manganese from made tea to its brew was in the range of 0.106 $0.424 \mathrm{mg} / \mathrm{kg}$. The Fe content in fresh tea leaves, made tea and its brew was found in the range of $9.01-9.7 \mathrm{mg} / \mathrm{kg}$, $0.275-0.40 \mathrm{mg} / \mathrm{kg}$ and $0.068-0.085 \mathrm{mg} / \mathrm{kg}$. The zinc content in green shoot of tea garden was found in ranged of $4.27-7.1 \mathrm{mg} / \mathrm{kg}$, while in processed made tea and its infusion, the total concentration of zinc found in the range of $0.080-0.10 \mathrm{mg} / \mathrm{kg}$ and $0.098-0.523 \mathrm{mg} / \mathrm{kg}$. The transfer of micronutrient $\mathrm{Zn}$ metal from leaves to infusion was about $1.45 \%-12.24 \%$. While, $\mathrm{Cu}$ the other micronutrient was tested in fresh tea leaves, made tea and its infusion ranged between 2.17 - $3.69 \mathrm{mg} / \mathrm{kg}, 0.092$ $0.57 \mathrm{mg} / \mathrm{kg}$ and $0.008-0.040 \mathrm{mg} / \mathrm{kg}$. The percentage dissipation of $\mathrm{Cu}$ from fresh tea leave to infusion was ranged from $0.2 \%-1.8 \%$.

\section{Discussion}

The $\mathrm{pH}$ (4.65 to 5.32) of soil showed acidic in nature, and it is mentioned that acidification is advanced in the tea garden soils [11]. Soils with low $\mathrm{pH}$ contain high amounts of $\mathrm{Fe}$ and $\mathrm{Al}$ oxides [18]. Lower content of organic matter may be due to less application of organic matter in the tea experimental farm. The nitrogen was the second most abundantly found in tea garden after potash and phosphorus.

Fortunately, the concentration of toxic heavy metals $\mathrm{Pb}, \mathrm{Ni}$ and $\mathrm{Cd}$ in tea leaves, made tea and its infusions were too low or not detected in this study. However, there are reports of the availability of these metals at lower levels in different blended tea leaves. Al-Qud in 2003 [13] has reported level of $\mathrm{Cd}$ within a range of nil $0.18 \mathrm{mg} / \mathrm{kg}$. Shen et al. 2008 [19] reported that cadmium content in the tea infusion were in the ranged of 0.005 $0.006 \mathrm{mg} / \mathrm{kg}$. On the other hand, level of $\mathrm{Pb}$ was reported within a range of $0.03-14.84 \mathrm{mg} / \mathrm{kg}$. According to Lagerwerff (1972) [20] Pb emitted in exhaust fumes of petrol combustion as minute particles of inorganic $\mathrm{Pb}$ compounds accounts for about $80 \%$ of the total lead in the atmosphere. About $50 \%$ of this falls somewhere within the region of $100 \mathrm{~m}$ from the road, rendering $\mathrm{Pb}$ concentration to be higher in roadside soils and in its vegetation.

Some essential elements such as $\mathrm{Mn}, \mathrm{Zn}, \mathrm{Fe}$ and $\mathrm{Cu}$ were studied, which play vital to humans for growth, metabolism, and hormones balancing [19]. The Mn content in the tea infusion was reported in the ranged of 0.56 $7.9 \mathrm{mg} / \mathrm{kg}$ after $5 \mathrm{~min}$ extraction time [21]. Low level of phosphorus plays significant role in the metal uptake of $\mathrm{Mn}, \mathrm{Cu}$ and Ni especially [22]. Several studies demonstrated that plants take up metal by the phosphate pathway due to their chemical similarity [23-26]. Similar trend was observed in case of manganese it increases from location U1 to L1 as phosphorus decreases. Mn was predominant heavy metal found in the fresh tea leaves followed by the Fe. Similar findings have been reported that Mn was found in highest concentration followed by Fe in fresh leaves of tea [27]. AL-Qud 2003 [13] suggested the ability of the tea plant to accumulate heavy metals particularly $\mathrm{Mn}, \mathrm{Fe}$ and $\mathrm{Zn}$, to a lesser extent $\mathrm{Cu}$ and reported higher levels of $\mathrm{Mn}$ in the tea plant within the range of $390-900 \mathrm{mg} / \mathrm{kg}$. 


\section{Conclusions}

This study determined levels of toxic and essential heavy metal in tea garden soil, and its dissipation from fresh tea leaves to infusion. The result showed that the concentration of toxic heavy metals $\mathrm{Pb}, \mathrm{Ni}$ and $\mathrm{Cd}$ in tea leaves, made tea and its infusions were too low or not detected in this study. Plant essential metal concentration of $\mathrm{Mn}, \mathrm{Fe}$, $\mathrm{Zn}$, and $\mathrm{Cu}$ in the tea leaves decreased in the order of $\mathrm{Mn}$ $>\mathrm{Fe}>\mathrm{Zn}>\mathrm{Cu}$. The level of most abundant essential heavy metals in tea infusion was $\mathrm{Zn}$ ranging from (0.09$0.52 \mathrm{mg} / \mathrm{kg})$ followed by Mn $(0.10-0.42 \mathrm{mg} / \mathrm{kg})$. Such study helpful to assess environmental impact for the purposes of maintenance of tea quality and sustainable development of tea production.

\section{Acknowledgements}

The authors are grateful to Dr. P. S. Ahuja, Director, Institute of Himalayan Bioresource Technology (Council of Scientific \& Industrial Research), Palampur for providing all facilities encouragement throughout this research work.

\section{REFERENCES}

[1] The Tea Council, 2004.

http://www.teacouncil.co.uk.

[2] H. N. Graham, "Chemistry Consumption and Health Affects," In: G. A. Spiller, Ed., The Methylxanthine Beverages and Foods, Alan R Liss Inc., New York, 1984, pp. 29-74.

[3] J. Ruan and M. H. Wong, "Accumulation of Fluoride and Aluminium Related to Different Varieties of Tea Plant," Environmental Geochemical and Health, Vol. 23, No. 1, 2001, pp. 53-63. doi:10.1023/A:1011082608631

[4] T. K. Mondal, A. Bhattacharya, M. Laxmikumaran and P. S. Ahuja, "Recent Advances of Tea (Camellia sinensis) Biotechnology," Plant Cell Tissue Organ Culture, Vol. 76, No. 3, 2004, pp. 195-254. doi:10.1023/B:TICU.0000009254.87882.71

[5] A. Mehra and C. L. Baker, "Leaching and Bioavailability of $\mathrm{Al} \mathrm{Cu}$ and $\mathrm{Mn}$ from Tea (Camellia sinensis)," Food Chemistry, Vol. 100, No. 4, 2007, pp. 1456-1463. doi:10.1016/j.foodchem.2005.11.038

[6] W. J. Chong, T. D. Shao, Z. Kai and Y. L. Xian, "Factors Determining Copper Concentration in Tea Leaves Produced at Yuyao Country China," Food and Chemical Toxicology, Vol. 46, No. 6, 2008, pp. 2054-2061. doi:10.1016/j.fct.2008.01.046

[7] S. W. Souci, W. Fachmann and H. Kraut, "Food Composition and Nutrition Tables," German Research Institute for Food Chemistry, Ministry for Nutrition, Agriculture and Forestry, Bonn Wissenschaftliche Verlagsgesellschaft $\mathrm{mbH}$, Postfach 40, D-7000 Stuttgart 1. 3rd Edition, 1986/1988, p. 1001.

[8] J. J. Powell, T. J. Burden and R. P. H. Thompson, "In
Vitro Mineral Availability from Digested Tea: A Rich Dietary Source of Manganese," Analyst, Vol. 123, No. 8, 1998, pp. 1721-1724. doi:10.1039/a802131g

[9] S. Seenivasan, N. Manikandan and N. Muraleedharan, "Chromium Contamination in Black Tea and Its Transfer into Tea Brew," Food Chemistry, Vol. 106, No. 3, 2008, pp. 1066-1069. doi:10.1016/j.foodchem.2007.07.027

[10] Y. J. Yang, "The Sciences of China Tea Cultivation," Shanghai Science and Technology Publisher, Shanghai, 2005.

[11] A. H. Varnam and H. P. Sutherland, "Beverages: Technology, Chemistry and Microbiology," Chapman and Hall, London, 1994, pp. 126-189.

[12] M. A. Bosque, M. Schuhmacher and J. L. Domingo, "Concentration of Lead and Cadmium in Edible Vegetables from Tarragona Province Spain," Science of Total Environment, Vol. 95, 1990, pp. 61-70. doi:10.1016/0048-9697(90)90053-W

[13] S. S. AL-Qud, "Heavy Metal Contents in Tea and Herb Leave," Pakistan Journal of Biological Sciences, Vol. 6, 2003, pp. 208-212. doi:10.3923/pjbs.2003.208.212

[14] S. Lee, M. Kim and Y. Hee, "Effect of Korean Green Tea, Oolong Tea and Black Beverage on the Removal of Cadmium and Antioxidative Detoxification in Cadmium Administered Rates," The Third International Symposium on Green Tea, Seoul, 1 September 1995.

[15] X. Cao, G. Zhao, M. Yin and J. Li, "Determination of Ultratrace Rare Elements by Inductively Coupled Plasma Mass Spectrometery with Microwave Digestion and AG50W-X8 Cation Exchange Chromatography," Analyst, Vol. 123, No. 5, 1998, pp. 1115-1119. doi:10.1039/a708881g

[16] P. K. Gupta, "Soil, Plant, Water and Fertilizer Analysis," Agrobios, New Delhi, 2000.

[17] ICH Harmonised Tripartite Guideline, "Text on Validation of Analytical Procedures," 1994. http//www.ich.org.

[18] Q. Hu, G. Pan and J. Zhu, "Effect of Fertilization on Selenium Content of Tea and the Nutritional Function of Se-Enriched Tea in Rats," Plant Soil, Vol. 238, No. 1, 2002, pp. 91-95. doi:10.1023/A:1014266613165

[19] F. M. Shen and H. C. Wen, "Element Composition of Tea Leaves and Tea Infusion and Its Impact on Health," Bulletin of Environmental Contamination and Toxicology, Vol. 80, No. 3, 2008, pp. 300-304. doi:10.1007/s00128-008-9367-z

[20] J. V. LagerwerffIn, J. J. Mottvedt, P. M. Giordano, et al., "Lead Mercury and Cadmium as Environmental Contaminants, Micronutrients in Agriculture Madison," Soil Science Society America, 1972, pp. 593-636.

[21] R. Street, J. Száková, O. Drábek and L. Mládková, “The Status of Micronutrient $(\mathrm{Cu}, \mathrm{Fe}, \mathrm{Mn}, \mathrm{Zn})$ in Tea and Tea Infusion in Selected Samples Imported to the Czeck Republic," Czeck Journal of Food Science, Vol. 25, No. 2, 2006, pp. 62-71.

[22] S. Natrajan, R. H. Stamps, U. K. Saha and L. Q. Ma, "Effect of Nitrogen and Phosphorus Levels and Frond-Har- 
vesting on Absorption Translocation and Accumulation of Arsenic by Chinese Brake Fern (Pteris vittata L.)," International Journal of Phytoremediation, Vol. 11, No. 4, 2009, pp. 313-328. doi:10.1080/15226510802564918

[23] A. A. Mehrag and M. R. Macnair, "An Altered Phosphate-Uptake System in Arsenate-Tolerant Holcus lantus L.," New Phytology, Vol. 116, No. 1, 1990, pp. 29-35. doi:10.1111/j.1469-8137.1990.tb00507.x

[24] A. A. Mehrag and M. R. Macnair, "Uptake Accumulation and Translocation of Arsenate in Arsenate-Tolerant and Non-Tolerant Holcus lantus L.," New Phytology, Vol. 117, No. 2, 1991, pp. 225-231. doi:10.1111/j.1469-8137.1991.tb04903.x

[25] A. A. Mehrag, J. Naylor and M. R. Macnair, "Phosphorus
Nutrition of Arsenate-Tolerant and Non-Tolerant Phenotype of Velvetgrass," Journal of Environmental Quality, Vol. 23, No. 2, 1994, pp. 234-238. doi:10.2134/jeq1994.00472425002300020003x

[26] A. A. Mehrag and J. Hartley-Whitaker, "Arsenic Uptake and Metabolism in Arsenic Resistant and Non-Resistant Plant Species," New Phytology, Vol. 154, No. 1, 2002, pp. 29-35. doi:10.1046/j.1469-8137.2002.00363.x

[27] M. Yemane, B. S. Chandravanshi and W. Taddese, "Levels of Essential and Non Essential Metals in Leavea of Tea Plant Camellia sinensis L. and Soil of Wushwush Farm Ethiopia," Food Chemistry, Vol. 107, No. 3, 2008, pp. 1236-1243. 